\title{
Jirqa Learning Strategies: Influence Student Learning Outcomes Based on Motivation Level
}

\author{
Silfi Faizatuluhmi ${ }^{1, a *}$, Ratna Komala ${ }^{1, b}$, Rusdi $^{1, c}$ \\ ${ }^{1}$ Department of Biology Education, Faculty of Mathematics and Natural Sciences, Jakarta State University, Jakarta, 13220, Indonesia \\ a silfifaizatuluhmi28@gmail.com; b ratna_komala08@yahoo.co.id, crusdi@unj.ac.id \\ ${ }^{*}$ Corresponding Author \\ Whatsapp Number [ 085716962322 ]
}

How to Cite : Faizatuluhmi S., Komala R., Rusdi. (2020). Jirqa Learning Strategies: Influence Student Learning Outcomes Based on Motivation Level. International Journal for Educational and Vocational Studies, 2 (8), 737-741. DOI: https://doi.org/10.29103/ijevs.v2i8.2763

\section{ARTICLE HISTORY}

Received: 6 May 2020

Revised: 13 June 2020

Accepted: 28 July 2020

KEYWORDS

Learning Outcomes;

JiRQA;

Motivation ;

\section{ABSTRACT}

The current learning process emphasizes the development of student skills as life skills, one of the goals is effective communication skills that are helped through knowledge from reading results. A syntactic integration between Jigsaw learning strategies and Reading, Questioning, Answering or called JiRQA learning strategies based on motivation level of student learning outcomes can help students to face the demands of the 21st century. This study aims to measure the effect of using JiRQA learning strategies based on motivation level of student learning outcomes. The research method is quasi-experimental. Data analysis was performed in the normality test using the Kolmogorov-Smirnov test, while the homogeneity test was carried out with the Bartlett test then for the hypothesis test carried out with a $2 \times 2$ factorial experimental design. The sample size was 18 experimental class students and 18 control class students in SMAN 11 Pandeglang. The results of the study showed normal and homogeneous $(p>0.05$ ). The results of the study using two-ways ANAVA test obtained data that the value of $p=0.014$, which means $p<0.05$ (starting $\mathrm{Ho}$ ). And make conclusions there is an interaction between JiRQA learning strategies based on the level of motivation on learning outcomes. Similar research needs to be done to get more information. The research findings are the influence of syntactic integration between Jigsaw and Reading, Questioning, Answering learning strategies on learning results based on motivation level.

This is an open access article under the CC-BY-SA license.

\section{INTRODUCTION}

Today, the purpose of education in Indonesia is to build 21st century skills, including critical thinking, problem solving, effective communication and collaborative skills. Effective communication skills will make it easy for students to give arguments, develop ideas and responses and dare to ask question about material that cannot be understood or are having difficulty understanding the material.

Based on the results of the review of problems at SMAN 11 Pandeglang, several learning strategies that can help students to communicate have been implemented, one of which is a jigsaw learning strategy. But at the stage of the process to deliver students' opinions, they found the difficulties to explain because of the lack of material they read. Students who have low interest in reading will affect the quality of low human resources, while at this time our country will face MEA (Asean Economic Community) so that the low desire of students in reading will be difficult for them to compete with the people from other countries in Asean. In addition, problems that were found were on average $65 \%$ of student learning outcomes under the KKM. This shows that the lack of achievement of student learning outcomes. While good quality learning will certainly produce good learning outcomes. Learning outcomes include cognitive, effective and psychomorphic (Liu, 2016).

The acquisition of learning outcomes that are still many under the KKM is influenced by several factors, one of which is student motivation. Learning motivation is an encouragement that arises from within and outside the individual to make changes in behavior. In addition, the maximum value of learning outcomes can be caused by the learning quality (Nikou, 2016). Quality learning outcomes are influenced by the appropriateness of implementing learning strategies (Juweto, 2015). Peer tutors are expected to provide feedback on each student to understand material that is less understood so that it helps students to master the material and improve 
student learning outcomes. In the peer tutor activities in learning JiRQA will give responsibility to each student to master the material being studied. Peer guidance activities make students think deeper so that they practice their ability to analyze and interpret the material being discussed (Bustami, 2016).

According to Bustami (2017) that the JiRQA learning strategy is a syntactic integration between Jigsaw and Reading learning strategies, Questioning, Answering (RQA), with seven stages as follows: (1) stating the learning topic, (2) forming an original heterogeneous group, (3) reading, questioning, answering in the original group, (4)) forming expert groups, (5) discussion in expert groups (6) discussion in peer tutors in the original groups, (7) giving quiz and group gifts and giving homework to read and summarize related material to be studied. Therefore the JiRQA learning strategy is able to actively involve students through several stages in learning activities. Stages in JiRQA learning activities such as forming groups, discussing, reading, question-answer, answering and peer tutoring are considered to be able to help students to improve the critical thinking skills of biology students (Bustami, 2016).

Based on the findings of Beni (2019) in his research that the peer tutor activities in the JiRQA learning strategy are able to make students think deeper so that they will train their ability to analyze and interpret the material discussed so that it can help student learning outcomes. According to Van Offenbeek (2001) concluded that working in peer tutors deepens the learning experience with a deep understanding. In addition, peer tutors can influence student learning outcomes (Boleng and Corebima, 2014).

This study provides an overview of the effect of JiRQA learning strategies on student learning outcomes based on the motivation levels. Right, this study answers the following questions: 1) Is there an influence of JiRQA learning strategies on learning outcomes? 2) Is there an influence between student learning motivation on learning outcomes? 3) Is there an interaction between JiRQA learning strategies and the level of motivation on student learning outcomes.

This research can improve $\mathrm{s}$ student learning outcomes which are alternatives in developing innovative learning strategies. Meanwhile it also has a positive influence to help students increase their motivation to learn to be able to influence their learning outcomes.

\section{MATERIALS AND METHODS}

This research used a quasi-experimental method to determine the effect of learning strategies and motivation levels on student learning outcomes s. The learning strategies in this study were divided into two, namely the JiRQA learning strategy for the experimental class and the RQA learning strategy for the control class. While the motivation in this research includes high and low motivation. So the design used is a $2 \times 2$ factorial experiment design.

Tabel 1. $2 \times 2$ Factorial Experiment Design

\begin{tabular}{ccc}
\hline \multirow{2}{*}{$\begin{array}{c}\text { Motivation } \\
(\mathrm{B})\end{array}$} & \multicolumn{2}{c}{ Learning Strategies $(\mathrm{A})$} \\
\cline { 2 - 3 } & Experimental class $\left(\mathrm{A}_{1}\right)$ & $\begin{array}{c}\text { Control class } \\
\left(\mathrm{B}_{2}\right)\end{array}$ \\
\hline High $\left(\mathrm{B}_{1}\right)$ & $\mathrm{A}_{1} \mathrm{~B}_{1}$ & $\mathrm{~A}_{2} \mathrm{~B}_{1}$ \\
\hline Low $\left(\mathrm{B}_{2}\right)$ & $\mathrm{A}_{1} \mathrm{~B}_{2}$ & $\mathrm{~A}_{2} \mathrm{~B}_{2}$ \\
\hline
\end{tabular}

The population in this study were all students of XI MIPA class as many as 132 students consisting of 4 (four) classes in semester 1 of 2019/2020 teaching at SMAN 11 Pandeglang. Determination of the research sample by simple random sampling. The number of samples used was 33 students in the experimental class and 33 students in the control class.

Before the learning strategy is applied in the classroom, first the non-motivation test instrument in the form of a questionnaire is given to the experimental class and the control class to find out the students with high motivation and students with low motivation. After grouping the motivation of students is obtained, followed by the application of learning strategies. At the end of the study a final test was conducted to determine student learning outcomes based on student motivation groups.

This study will confirm the following hypotheses: 1) JiRQA learning strategies have an influence on student learning outcomes; 2) the level of student learning motivation has an influence on student learning outcomes; 3) JiRQA learning strategies and levels of student motivation have interactions with student learning outcomes.

\section{RESULTS AND DISCUSSIONS}

Before the implementation of learning strategies in class, first the non-motivation test instrument in the form of a questionnaire was given to the experimental class and the control class to find out students with high motivation and students with low motivation.

The samples are grouped based on the level of student motivation which is done by classifying student scores obtained by means of 33 students answering 30 statements of learning motivation instruments. Calculation of $27 \%$ of 33 students obtained 9 results, then 9 students in the top order and 9 students in the lowest order are classified as students with low learning motivation. According to Naga (1992) that to determine the high and low groups the high and low groups were chosen which are quite contrasting, but quite reliable and such optimum size is achieved when the high and low groups account for $27 \%$ of the total number of students. The acquisition of student grouping outcomes is shown in Table 2.

The results obtained after filling the instrument of learning motivation between the experimental class and the control class are not much different because there is no application of learning strategies. In the experimental 
class the highest value obtained is 87 while in the control class the highest value is 85 . As for the lowest value in the experimental class obtained is 60 while in the control class 55.

There are two datas in this study namely student motivation data and student's learning results of the subject being studied namely cell matter. The data is divided into 4(four) data groups namely (1) Student learning outcomes using JiRQA learning strategies with students who had high motivation totaling 9 students; (2) Student learning outcomes used the JiRQA learning strategies with 9 students having low motivation; (3) Student learning outcomes used RQA learning strategies with 9 highly motivated students; and (4) Student learning outcomes used RQA learning strategies with 9 students having low motivation.

Testing the hypothesis of this study used $2 \times 2$ factorial design with 2 -ways Anava technique. This test is carried out to compare the average difference between groups that have been divided based on learning strategies and the level of student motivation. The results of the hypothesis test are presented in Table 3.

In Table 3 shows the results of the answer to the first hypothesis that is based on a significance value of 0.000 , where the value of $\mathrm{p}<0.05$ then reject Ho and concluded that there are significant differences in learning outcomes between groups of students who are given JiRQA learning strategies with groups of students who are given strategies RQA learning. Because according to Bustami (2017) that the stages of the JiRQA learning strategy each student seems to be an expert in their field, thus encouraging students to learn more independently.

Table 2. Student Grouping Outcomes

\begin{tabular}{cccc}
\hline Student Motivation Level & Experiment Class & Control Class & Note \\
\hline Height & 9 & 9 & Sample \\
Medium & 15 & 15 & Not a sample \\
Low & 9 & 9 & Sample \\
\hline
\end{tabular}

Table 3. 2-Ways Anava Hypothesis Test Outcomes Table

\begin{tabular}{cccccc}
\hline Source & $\begin{array}{c}\text { Type III Sum } \\
\text { of Squares }\end{array}$ & Df & Mean Square & F & Sig \\
\hline Corrected Model & $6441.875^{\mathrm{a}}$ & 3 & 2147.292 & 42.886 & .000 \\
Intercept & 191130.625 & 1 & 191130.625 & 3817.311 & .000 \\
Learning Model & 1380.625 & 1 & 1380.625 & 27.574 & .000 \\
Motivation & 4730.625 & 1 & 4730.625 & 94.481 & .000 \\
Learning Model & 330.625 & 1 & 330.625 & & \\
Motivation & 1802.500 & 32 & 50.069 & & \\
Error & 199375.000 & 36 & & & \\
Total & 8244.375 & 35 & &
\end{tabular}

a.R Squared $=.435($ Adjusted R Squared $=.411)$

Table 4. Tukey Test Results Multiple Comparisons

Dependent Variable: Learning Result of Cell Material Tukey HSD

\begin{tabular}{ccccc} 
(I) Data Groups & (J) Data Groups & Mean Difference (I-J) & Std. Error & Sig. \\
\hline \multirow{3}{*}{ A1B1 } & A1B2 & $11.500^{*}$ & 2.736 & .001 \\
& A1B1 & $17.000^{*}$ & 2.736 & .000 \\
A1B2 & A2B2 & $32.000^{*}$ & 2.736 & .000 \\
& A1B1 & $-11.500^{*}$ & 2.736 & .001 \\
A2B1 & A2B1 & 5.500 & 2.736 & .203 \\
& A2B2 & $20.500^{*}$ & 2.736 & .000 \\
& A1B1 & $-17.000^{*}$ & 2.736 & .000 \\
A2B2 & A1B2 & -5.500 & 2.736 & .203 \\
& A2B2 & $15.000^{*}$ & 2.736 & .000 \\
& A1B1 & $-32.000^{*}$ & 2.736 & .000 \\
& A1B2 & $-20.500^{*}$ & 2.736 & .000 \\
\hline
\end{tabular}

*The mean difference is significant at the .05 level 
Then Bustami (2017) continues her opinion that analyzing material with student critical thinking can contribute to students' cognitive abilities. The cognitive domain consists of remembering, understanding, applying, analyzing, evaluating and creating. The domain is part of the learning results category.

The application of learning strategies from both classes is based on observation sheets and lesson plans. When the implementation of the strategy begins first students are instructed to read at home so that students have knowledge before discussion in the learning process, students are expected to be able to understand the material first. but this is a contradictory aspect because of limitations in direct observation. Although when the learning process takes place each student is observed to be more active through peer tutors.

Further data analysis in Table 3 regarding the effect of learning motivation on student learning outcomes. Based on a significant value of 0,000 , where the value of $p>$ 0.05 then reject $\mathrm{Ho}$ and concluded that there are significant differences in learning outcomes between groups of students who have high motivation and students who have low motivation. Because according to Setyowati (2007) that students who have high motivation will work harder than students who lack motivation or low motivation. Then confirmed by Harandi (2015) that high motivation will have an impact on student learning outcomes.

The level of student motivation can be observed from perseverance in learning, a sense of responsibility, seriousness in learning, high curiosity, being able to complete assignments on time and being able to work well together. So that the attractiveness of students in learning increases which affects student motivation.

In the next data found in Table 3 is 0.014 which means the value of $p<0.05$ is Ho is rejected. These results indicate that there is an interaction between JiRQA learning strategies and motivation levels on student learning outcomes. So that there is an interaction, the statistical test is continued using the tukey test. The calculation is done to test 3 hypotheses that measure the difference in mean between groups of data. The results of the tukey test are presented in Table 4 .

Based on the data and observations obtained from the evaluation of learning outcomes, there is an interaction because the JiRQA learning strategy helps students understand the material presented in the learning process through the syntax stages possessed by the JiRQA learning strategy. According to Bustami (2016) that the JiRQA learning strategy is able to actively involve students through several stages in learning activities. Stages in learning JiRQA such as forming groups, discussing, reading, asking questions, answering questions, answering and peer tutoring are considered to help students to think critically about biology students. According to Juweto (2015) that peer tutoring activities at the JiRQA learning strategy stage will "force" each student to share or present their part of the learning material to their peers. Courage to present learning materials can encourage students who are ultimately able to improve students' cognitive abilities.

The results are observed that students have a desire to read, and there is an effort in the learning process both in teams and individually which can be said that they have motivation. According to Sahbaz (2012) revealed that students with higher learning motivation will produce higher learning results, namely there is a positive relationship between learning motivation and learning outcomes.

From the discussion, new things in this study are evidenced by the interaction between JiRQA learning strategies and the level of learning motivation. This finding will be useful for teachers in teaching by stimulating student motivation. One learning strategy that can be used to stimulate motivation and improve student learning outcomes is the JiRQA learning strategy.

\section{CONCLUSION}

Based on the results and discussion, it was found that the application of JiRQA learning strategies in biology learning was able to produce better student learning outcomes based on motivation levels. In general, based on the results of the 2 - ways ANAVA test that is 0.014 on the results of the study indicate that there is an interaction between learning strategies and motivation because $\mathrm{p}<$ 0.05 means starting Ho. Then based on observations, students tend to be more active in discussions in understanding the material being studied so that it affects student learning outcomes. This is because motivation is directly proportional to the value of student learning outcomes.

\section{REFERENCES}

Beni, Bustami, Y., Leliavia. (2019). Implementasi Strategi pembelajaran Kooperatif Tipe JiRQA terhadap Kemampuan Berpikir Kritis Siswa pada Materi Pertumbuhan dan Perkembangan Tumbuhan. Edubiotik, 4(1): 9-15.

Boleng D. T. \& Corebima, A. D. (2014). Cooperative Learning Models Having Better Potency to Improve Social Attitude of Multiethnic Senior High School Students at Samarinda, Indonesia. Journal of Educational Research and Reviews, 2(3): 36-44.

Bustami, Y. dan Corebima, A. D. (2017). The Effect of JiRQA Learning Strategy on Critical Thinking Skills of Multiethnic Students in Higher Education, Indonesia. International Journal of Humanities Social Sciences and Education (IJHSSE), 23(1): 13-22.

Bustami, Y., Suarsini, E., \& Ibrohim. (2016). How to Empower Students' Critical Thinking Skill in Higher Education Through JiRQA Learning Strategy: A Review of Innovation Cooperative Learning Strategy. International Journal of Education and Science Research Review (IJESRR), 28(2:, 26-38. 
Bustami, Y., Suarsini, E., Ibrohim., \& Corebima, A. D. (2017). The Social Attitude Empowerment of Biology Students: Implementation JiRQA Learning Strategy in Different Ethnics. International Journal of Instruction, 10(3): 15-30.

Harandi, S. R. (2015). Effects of E-Learning in University Study. Procedia-social and Behavioral Sciences, 112(5): 309-313.

Juweto, G. A. (2015). Effects of Jigsaw Co-Operative Teaching / Learning Strategy and School Location on Students Learning Outcomes and Attitude Towords Biology in Secondary School in Delta State. International Journal of Education and Research, 3(8): 31-40.

Kumpas-lenko, K. (2018). Does the Design of Learning Outcomes Matter from Students' Perspective?. Studies in Educational Evaluation, 59(18): 179-186.

Liu, M. H. (2016). Blending a Class Video Blog to Optimize Student Learning Outcomes in Higher Education. Internet and Higher Education, 1(1): 253-260.

Naga, D. S. (1992). Pengantar Teori Sekor pada Pengukuran Pendidikan. Jakarta: Gunadarma.

Nikou, S. A. (2016). The Impact of Paper-Based, Computer-based and Mobile-Based Self-Assessment on Students Science Motivation and Achievement. Journal Computer and Phycycology, 1(1): 90-99.

Şahbaz, N. K. (2012). Evaluation of Reading Attitudes of 8th Grade Students in Primary Education According to Various Variables. Educational Research and Reviews, 7(26): 571-576.

Setyowati. (2007). Pengaruh Motivasi Belajar Terhadap Hasil Belajar Siswa Kelas VII SMPN 13 Semarang. Jurnal Pendidikan Sains, 1(1): 12-18.

Van Offenbeek, M. (2001). Processes and outcomes of team learning. European Journal of Work and Organizational psychology, 10(3): 303-317. 